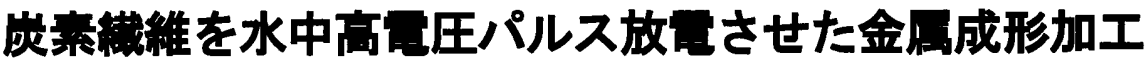

\author{
前原 弘法 ${ }^{* 1}$ ，前園 漱 ${ }^{* 2}$ ，西 雅俊 ${ }^{* 3}$ ，田中 茂 ${ }^{* 4}$, 外本 和幸 ${ }^{* 5}$
}

\section{Metal forming process using the carbon fiber by the underwater high voltage pulse discharge}

\author{
Hirinori MAEHARA ${ }^{* 1}$ and Sou MAEZONO, Masatoshi NISHI, Shigeru TANAKA, \\ Kazuyuki HOKAMOTO \\ ${ }^{* 1}$ Kumamoto Univ. Institute of Pulsed Power Science \\ 2-39-1 Kurokami, Chuo-ku, Kumamoto City, Kumamoto, 860-8555 Japan
}

Some high-rate metal forming techniques using explosives and others have been studied until now. This study utilizes the energy for metal forming by a high voltage pulse discharging of carbon fibers in underwater which enables to induce underwater shock wave efficiently. The experimental procedure and the deformation features are demonstrated.

Key Words : Metal forming, Carbon fiber, High voltage discharg, Underwater shock wave, Bubble pulse, Titaniium plate

\section{1. 精}

板材の高エネルギ一加工の代表的なものに, 火薬類の爆発エネルギーを利用する爆発成形(1)(2), 衝撃大電流を利 用する放電成形や電磁成形, 高圧ガスによるピストンの高速駆動を利用する高速押し出しや高速鍜造などがある。 本研究では, 比較的小型の衝撃大電流による水中放電の装置を用いて, チタン板 TP270 の成形を試みた。特にこ こでは電極間に炭素繊維を配置し，大電流を瞬間的に放電することによって，板の自由張出し成形を行った。水 中放電の場合には，水中にバブルが生じ、これによる繰り返しの圧力作用によってチタン板の成形性の改善が期 待される。

\section{2. 实臨方法}

使用した実験装置の概略図を, 図 1 に示す。また, 高電圧放電成形装置の諸元を表 1 に示す。対向させて水中 に設置した電極間に炭素繊維 $6 \mathrm{~K}$ を長さ $50 \mathrm{~mm}$ に固定して, 高さ $15 \mathrm{~mm}$ 離した位置にチタン板を固定して放電し た。ちなみに炭素繊維を用いずに水中でギャップ放電を行う場合は，充電電圧 $3000 \mathrm{~V}$ ，充電エネルギー3.6 $\mathrm{kJ}$ 以上 のエネルギーが必要となり，バブルの発生は数ミリの電極間の 1 箇所からとなる。これに対して，炭素繊維を用 いることで, 繊維を起点として円筒状に広い範囲で放電およびバブルが発生することになり，少ない充電電圧で 水中ギャップ放電と同等のエネルギーを発生することができる。

ここで用いた金属型の寸法は，内径 $100 \mathrm{~mm}$ ，肩部の半径は $5 \mathrm{~mm}$ である。また，チタン板の材質は TP270 で， 直径 $140 \mathrm{~mm}$ ，厚さ $0.3 \mathrm{~mm}$ のものを試料として用いた。

成形された材料は，張り出し高さの測定を実施するとともに，スクライブドサークル試験による板の歪測定を 行った。

\footnotetext{
${ }^{* 1}$ 正員, 熊本大学 パルスパワー科学研究所（广860-8555 熊本県熊本市中央区黒髪 2 丁目 39-1）

*2 非会員, 熊本大学 パルスパワー科学研究所

*3 正員, 熊本高等専門学校 機械知能システム工学科

*4 正員, 熊本大学 工学部

*5 正員, 熊本大学 パルスパワー科学研究所

E-mail: maehara@mech.kumamoto-u.ac.jp
} 


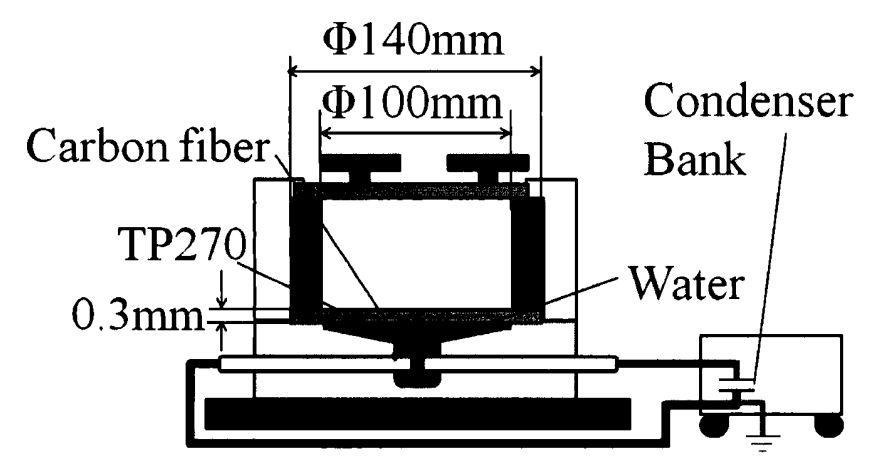

Table 1 Experimental condition.

\begin{tabular}{|c|c|}
\hline Charge voltage & $2000 \mathrm{~V}$ \\
\hline Electrostatic capacity & $800 \mathrm{uF}$ \\
\hline Electrostatic energy & $1.6 \mathrm{~kJ}$ \\
\hline Processing count & 1 \\
\hline
\end{tabular}

Fig.1 Assembly used for experiments.

\section{3. 实験結果}

成形後の写真を図 2 に示す。試料に破断は生じていないものの，材料が型に引き込まれたことによって，肩部 周辺にしわが確認された。このときの張出し高さは, $19 \mathrm{~mm}$ であった。ギャップ放電で同様の張り出し高さを達 成するには，前述したように，より大きな充電エネルギーが必要であった。

ここでひずみ分布についての詳細は省略するが，板の中央はほとんど変形していない一方で、半径 $20 \mathrm{~mm}$ から 肩周辺部 $55 \mathrm{~mm}$ にかけて歪みが発生している状況であった。
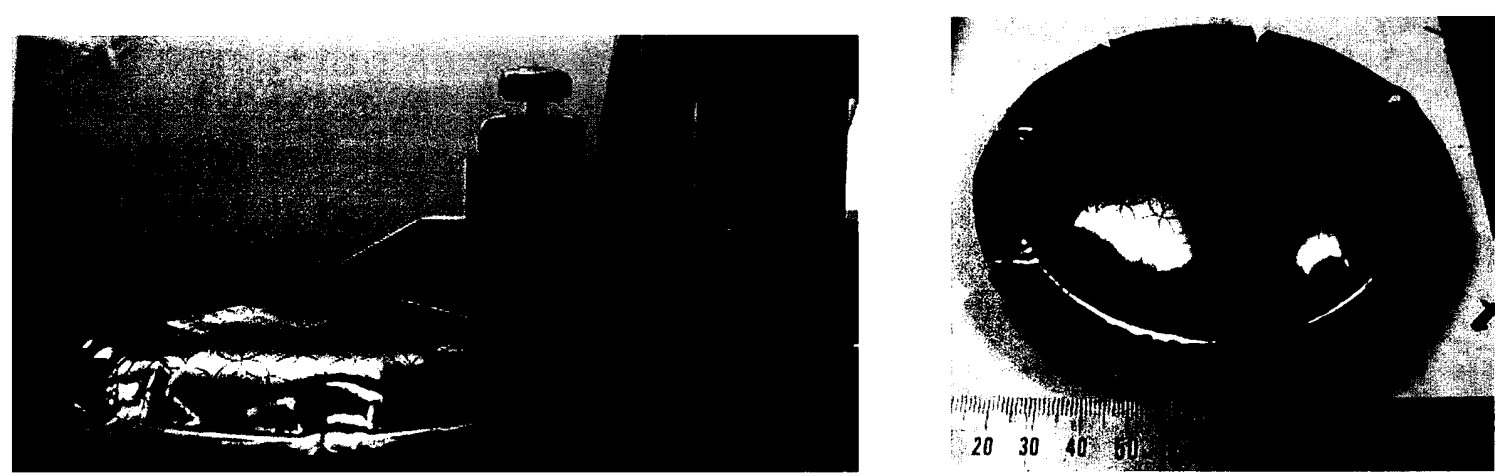

Fig.2 Appearance of the formed Ti plate.

\section{4. 結}

電極間に炭素繊維を設置し放電させることで, ギャップ放電の時よりも低い電圧, 少ないエネルギーで TP270 を自由張出し成形するのに十分なエネルギーを発生させることができた。

的 辞

本研究は, 平成 25 年度科学研究費補助金 (奨励研究) 25917003 の助成を受けたものである.

\section{文嗝}

（1）伊東 繁, 井山 裕文, 村本 聡, 長野 司郎, 村田 健司, 加藤 幸夫 “水中衝撃波を用いた自由張出し成形に関する 研究 : 爆薬配置の偏心球状成形への影響”, 日本機械学会九州支部講演論文集, Vol. 18-2, No. 303 (2001), pp. 79-80.

(2) 伊東 繁, 井山 裕文, 松村 亮, 長野司郎, “水中衝撃波を用いた薄板の任意形状自由張り出し成形”, 日本機械 学会九州支部講演論文集, Vol. 18-2, No. 304 (2001), pp. 81-82. 